\title{
South - East Asian Integration in the Context of OIC: Implications of Free Trade among Malaysia, Indonesia and Bangladesh
}

\author{
Mustafa ACAR \\ Kirikkale University \\ Savas ALPAY \\ SESRIC \\ Esat BAKIMLI \\ SESRIC \\ Zehra Zümrüt KOC \\ SESRIC
}

\begin{abstract}
Organization of the Islamic Conference (OIC) is the second largest intergovernmental organization after UN with its 57 members. OIC accounts for 22.48 percent of world population, 6.64 percent of world GDP, and 9.1 percent of world trade as of 2007. When it comes to having world valuable resources, OIC's potential is even more striking with more than $70 \%$ of oil and nearly $50 \%$ of natural gas reserves of the world. However, the level of economic integration and volume of trade among OIC members over the last 4 decades has been less than satisfactory. But recently there have been some efforts towards increased economic cooperation among the member countries as a key strategy for higher

\footnotetext{
*Corresponding address: Mustafa ACAR: Kirikkale University, Department of Economics, Kirikkale, Turkey, e-mail: ma@mustafaacar.com, Savas ALPAY: Director General, SESRIC, e-mail: salpay@ sesric.org, Esat BAKIMLI: Researcher, SESRIC, e-mail: ebakimli@ sesric.org, Zehra Zümrüt KOC: Researcher, SESRIC, e-mail: zkoc@ sesric.org 
economic growth and welfare. Protocol on Preferential Tariff Scheme (PRETAS) signed by nearly a dozen countries proposes a preferential trade regime among the member states. Further steps in the coming years, including possible free trade areas and customs union are also on the agenda. In this context, this paper looks into the likely consequences of an economic integration among three OIC member countries: Malaysia, Indonesia, and Bangladesh. This could be seen as a first step to investigate the possible gains from more comprehensive economic integration initiative including all members of the OIC. Using a multi-sector, multi-country computable general equilibrium framework, we investigate the impact of full trade liberalization among Malaysia, Indonesia and Bangladesh. One should stress that there is not a simple and clear-cut conclusion one can derive: depending on the nature and the degree of integration, the results vary. The simulation results indicate that free trade among these three countries will likely benefit Indonesia and Malaysia while leading to some welfare loss for Bangladesh. Based on the results, it can be suggested that mechanisms be developed in order to strengthen the adjustment capacity of the less developed trade partners. Correspondingly, instead of FTAs, preferential trade arrangements can be considered in the beginning in accordance with the priorities of countries focusing on certain sectors in which they have comparative advantage. Larger integrations may be achieved in the long term gradually through such small-scale integrations.

- JEL Classification : F13, F15, F17, R13, O50

- Key Words: OIC, East and South Asia, economic integration, GTAP, CGE Analysis, Malaysia, Indonesia, Bangladesh

\section{Introduction}

Free trade has long been acknowledged as a positive sum game, benefiting all parties involved. Along with the rapid process of globalization in recent decades, including liberalization of trade, this argument has brought about a worldwide debate on how to ensure a fare trade among countries to improve the global economic integration while seeking to facilitate economic development, increase welfare and help alleviate poverty. This process has generated a number of various agreements all over the world, varying from bilateral preferential trade agreements to world-scale integrations like the European Union. Accordingly, the number of trade agreements has showed an increasing trend in the world especially since the 
early 1990s. ${ }^{1}$

Organization of the Islamic Conference (OIC) is today the second largest intergovernmental organization after UN with its 57 members. OIC accounts for 22.48 percent of world population, 6.64 percent of world GDP, and 9.1 percent of world trade as of 2007. When it comes to having world valuable resources, OIC's potential is even more striking with more than $70 \%$ of oil and nearly $50 \%$ of natural gas reserves of the world. However, the level of economic integration and volume of trade among OIC members over the last 4 decades has been less than satisfactory. Efforts to develop the trade potential among the member countries of OIC date back to 1980s under various OIC forums. After deliberations in a number of meetings, a Framework Agreement on establishing a Trade Preferential System among the member states of the OIC (TPS-OIC) was adopted in 1990 and entered into force at the and of 2002 with the required number of 10 ratifying members. During the trade negotiations towards the implementation of the trade preferential system, the Protocol on Preferential Tariff Scheme for TPS-OIC (PRETAS, 2006) was produced and this was acknowledged as a concrete project whereby the trade barriers among member countries could be reduced within a specific time-frame in order to establish the TPS-OIC. ${ }^{2}$ Moreover, the Ten-Year Programme of Action adopted by the Third Extraordinary Session of the Islamic Summit Conference appeals for an expansion of the intra-OIC trade, currently about 15 percent, to the level of 20 percent by the end of the Programme period.

With these in mind, this study investigates the likely effects of a free trade agreement (FTA) among three members of the OIC-Bangladesh, Indonesia and Malaysia, hereafter stated as BIM. Among the regional trade agreements notified to the GATT/WTO, there is not any multilateral agreement covering these three countries. Of course, there are some regional trade agreements in which one or two of these countries participated. For instance, Bangladesh is a member of APTA, BIMSTEC, and SAFTA while Malaysia and Indonesia are members of AFTA and a number of other agreements signed between ASEAN and other countries (UNESCAP, 2008).

Hence, BIM is neither an existing nor a projected FTA. It is suggested since it is highly interesting that these countires do not have a multilatarel agreement though they are very close in terms of geographical distance. Because the Bangladesh -

There are some 380 Regional Trade Agreements (RTA) that have been notified to the GATT/WTO and 201 of them were in force as of 15 March 2008 (WTO RTA Gateway, http://www.wto.org/).

${ }^{2}$ For further information on TPS-OIC see http://www.comcec.org/ 
Indonesia - Malaysia FTA is a proposal and not a realized agreement, the outcomes obtained in the paper refer to ex ante simulations, but the same principles would be relevant for ex post studies of actual FTA agreements. ${ }^{3}$

The study employs the Computable General Equilibrium (CGE) modeling approach and using the Global Trade Analysis Project (GTAP) general equilibrium model. This model has been widely used in the literature to analyze the economic effects of FTAs. The rest of the paper is organized as follows: section II introduces the model and the dataset employed in the analysis as well as the context of the simulated scenario of FTA. The section III illustrates the pre-simulation situation, displaying a picture of the magnitude and structure of the trade among BIM in addition to tariffs and export subsidies they impose on their trade with each other. The section IV presents the results of the FTA simulation with evaluation of its effects on different macroeconomic aggregates of the respective parties focusing on changes in production, trade, and welfare. The section $\mathrm{V}$ concludes with a brief summary and evaluation of the outcomes of the study.

\section{Model, Dataset and the Scenario}

This paper employs the Computable General Equilibrium (CGE) modeling approach using the Global Trade Analysis Project (GTAP) general equilibrium model $^{4}$ and Gtap database version $6^{5}$ for a quantitative analysis of the macroeconomic effects of the studied FTA. The GTAP model allows for the assessment and the decomposition of the welfare effects of various trade agreements. Therefore, it has been widely used in the literature to study the likely effects of different trade agreements and other trade policy issues. ${ }^{6}$

The CGE model is based on commonly applied assumptions of constant returns to scale, perfect competition, and imperfect substitution between foreign and domestic goods and between alternative sources of imports (the Armington assumption). As the standard GTAP closure has been employed, the standard GTAP simulation conducted here represent only the static impacts of a policy

${ }^{3}$ In additition, we were bound to technical limitations of the GTAP database while choosing countries for which a FTA can be suggestable. Out of the 57 OIC Member Countries, only the following 9 of the OIC Member Countries were treated as a single region in GTAP database v.6: Indonesia, Malaysia, Bangladesh, Albania, Turkey, Morocco, Tunisia, Mozambique, Uganda.

${ }^{4}$ Full documentation of the theoretical structure of the GTAP model is available in Hertel (1997).

${ }^{5}$ The most recent Gtap database (version 7) was not available at the time of the analysis.

${ }^{6} \mathrm{~A}$ number of studies conducted using GTAP can be accessed at http://www.gtap.agecon.purdue.edu/ 
Table 1. Regional and Sectoral Aggregation

\begin{tabular}{|c|c|c|c|c|c|c|c|c|}
\hline \multicolumn{3}{|r|}{ Regions } & \multicolumn{6}{|c|}{ Sectors } \\
\hline & Code & Coverage & & Code & Coverage & & Code & Coverage \\
\hline 1 & BANG & Bangladesh & 1 & RAGR & Raw Agriculture & 5 & TXTL & $\begin{array}{c}\text { Textiles and } \\
\text { Wearing Apparels }\end{array}$ \\
\hline 2 & INDO & Indonesia & 2 & ANMP & Animal Products & 6 & HIND & $\begin{array}{l}\text { Other Industrial } \\
\text { Sectors }\end{array}$ \\
\hline 3 & MALY & Malaysia & 3 & FRAF & $\begin{array}{l}\text { Forestry and } \\
\text { Fishing }\end{array}$ & 7 & ENRG & Energy \\
\hline 4 & ROW & Rest of the World & 4 & PRFP & Processed Food & 8 & SVCS & $\begin{array}{l}\text { Services and } \\
\text { Activities NES }\end{array}$ \\
\hline
\end{tabular}

change, leaving out the dynamic effects that are attributable to increased investment, increased competition, and economies of scale. In the standard closure, it is assumed that there is no change in population; no change in technology of any sort; firms operate under perfect competition, hence they earn no positive economic profit; all markets clear; budget balance condition is satisfied; and lastly, there is no change in factor employment. It is also worth noting that among the four basic factors of production, land is specific to agriculture; unskilled labor is sluggish-degree of mobility is quite low; and skilled labor and capital are mobile between sectors. Also, factors are not internationally mobile.

The GTAP 6 Data Base, with the base year 2001, contains 57 sectors and 87 regions. The simulation presented here is based on an aggregated version of the data consisting of four regions and eight sectors, or groups of commodities. ${ }^{7}$ All other regions than Bangladesh, Indonesia, and Malaysia, the parties to the studied FTA, are aggregated into a single region as the rest of the world (ROW). The 57 sectors are aggregated into eight broader categories as described in Table 1 below.

The scenario simulated in this study is an establishment of an FTA among Bangladesh, Indonesia, and Malaysia, namely liberalization of merchandise trade among these countries with complete removal of import taxes as well as export subsidies, holding all other distortions in the system constant.

\section{Initial Case}

\section{A. Bilateral Trade}

Despite the efforts to increase trade among OIC member countries, trade among

${ }^{7}$ See Appendix 1 for the details of sectoral aggregation 
Table 2. Decomposition of Trade by Partner (\%)

\begin{tabular}{|c|c|c|c|c|c|c|}
\hline & \multicolumn{6}{|c|}{ Partner } \\
\hline & & BANG & INDO & MALY & ROW & Total \\
\hline \multirow{3}{*}{ 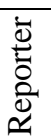 } & BANG & $\cdots$ & 1.88 & 1.38 & 96.74 & 100 \\
\hline & INDO & 0.27 & $\cdots$ & 3.32 & 96.41 & 100 \\
\hline & MALY & 0.11 & 1.91 & $\ldots$ & 97.98 & 100 \\
\hline
\end{tabular}

Source: GTAP Database V.6.

Bangladesh, Indonesia, and Malaysia is not satisfactory. The share of Indonesia and Malaysia in the total trade of Bangladesh is less than 2 percent: $-1.88 \%$ and $1.38 \%$, respectively (see Table 2). What is even worse is that Bangladesh accounts for less than $0.5 \%$ of the total trade of Indonesia and Malaysia: $0.27 \%$ and $0.11 \%$, respectively. This shows that Bangladesh, under the current conditions, does not trade much with these countries. This is also clear from the fact that Bangladesh, according to IMF's Direction of Trade Statistics for 2006, is ranked $38^{\text {th }}$ and $43^{\text {rd }}$ among the trade partners of Indonesia and Malaysia, respectively, with respect to its share in their total trade. Trade between Indonesia and Malaysia is relatively higher. Though the share of Malaysia in the total trade of Indonesia is 3.32\%, Malaysia is the top $6^{\text {th }}$ trading partner of Indonesia. Similarly, the share of Indonesia in the total trade of Malaysia is $1.91 \%$, yet it is the top $9^{\text {th }}$ trading partner of Malaysia.

Decomposition of exports by sector reveals that Bangladesh's exports heavily depend on textiles (TXTL) with a share of $76 \%$ in total exports while Malaysia and

Table 3. Decomposition of Exports by Partner Country and by Sector (\%)

\begin{tabular}{|c|c|c|c|c|c|c|c|c|c|c|c|c|}
\hline & \multicolumn{4}{|c|}{$\begin{array}{c}\text { Total Exports of } \\
\text { Bangladesh }\end{array}$} & \multicolumn{4}{|c|}{$\begin{array}{l}\text { Total Exports of } \\
\text { Indonesia }\end{array}$} & \multicolumn{4}{|c|}{$\begin{array}{l}\text { Total Exports of } \\
\text { Malaysia }\end{array}$} \\
\hline & $\overline{\mathrm{INDO}}$ & MALY & ROW & Total & BNGL & MALY & ROW & Total & BNGL & INDO & ROW & Total \\
\hline RAGR & 2.30 & 1.26 & 1.60 & 1.60 & 0.90 & 6.23 & 3.24 & 3.33 & 0.49 & 1.69 & 0.75 & 0.76 \\
\hline ANMP & 0.01 & 0.01 & 0.10 & 0.10 & 0.16 & 2.03 & 0.69 & 0.73 & 3.79 & 0.73 & 0.78 & 0.78 \\
\hline FRAF & 0.25 & 2.62 & 0.25 & 0.26 & 6.43 & 15.89 & 14.31 & 14.33 & 2.95 & 1.73 & 4.46 & 4.43 \\
\hline PRFP & 0.04 & 1.25 & 3.96 & 3.94 & 15.72 & 4.46 & 5.88 & 5.88 & 20.99 & 9.14 & 3.61 & 3.71 \\
\hline TXTL & 29.87 & 18.16 & 76.35 & 76.11 & 33.52 & 8.61 & 17.82 & 17.59 & 18.37 & 1.95 & 2.42 & 2.44 \\
\hline HIND & 42.16 & 51.67 & 6.93 & 7.12 & 40.98 & 57.64 & 37.68 & 38.32 & 49.57 & 59.56 & 67.20 & 67.08 \\
\hline ENRG & 0.01 & 0.01 & 0.04 & 0.04 & 1.60 & 3.58 & 14.14 & 13.75 & 0.88 & 4.01 & 3.89 & 3.89 \\
\hline SVCS & 25.36 & 25.02 & 10.76 & 10.83 & 0.70 & 1.55 & 6.24 & 6.07 & 2.95 & 21.18 & 16.88 & 16.91 \\
\hline Total & 100 & 100 & 100 & 100 & 100 & 100 & 100 & 100 & 100 & 100 & 100 & 100 \\
\hline
\end{tabular}


Indonesia focus on industrial products (HIND) with a share of $67 \%$ and $38 \%$, respectively (see Table 3 ). In this regard, Indonesia with relatively high shares of TXTL, FRAF, and ENRG as well has got a more diversified export structure.

Surprisingly, HIND has the highest share in the bilateral trade ${ }^{8}$ among Bangladesh, Indonesia, and Malaysia, ranging from 40 to $60 \%$. This clearly indicates that intra-industry trade among these three countries is significant in this sector. TXTL, which has the highest share in total trade of Bangladesh, is the second important sector in the trade between Bangladesh and Indonesia. It constitutes almost $30 \%$ of Bangladesh's exports to Indonesia, and one third of exports of Indonesia to Bangladesh. On the other hand, FRAF, after HIND, is an important sector in exports of Indonesia to Malaysia with a share of $15.9 \%$. As for Malaysia, a highly dependant country on HIND exports, PRFP and TXTL exports to Bangladesh and PRFP exports to Indonesia are also important.

\section{B. Import Taxes and Export Subsidies}

Tariffs and other taxes are represented in the GTAP database as ad valorem equivalent of the actual rates. Table 4 shows the import taxes on bilateral trade taken from the GTAP database. Bangladesh applies high taxes on its imports from all over the world including Indonesia and Malaysia. Except for ENRG imports from Indonesia, the tariff level on imports from Indonesia and Malaysia ranges from 18 to $29 \%$ in all of the sectors. Indonesia and Malaysia, on the other hand, seem to have a more liberalized trade. In Indonesia, the highest import tariffs on

Table 4. Import Taxes by Trading Partner (Base Case) (\% Ad Valorem Rate)

\begin{tabular}{|c|c|c|c|c|c|c|c|c|c|}
\hline & \multicolumn{3}{|c|}{ Bangladesh } & \multicolumn{3}{|c|}{ Indonesia } & \multicolumn{3}{|c|}{ Malaysia } \\
\hline & INDO & MALY & ROW & BANG & MALY & ROW & BANG & INDO & ROW \\
\hline RAGR & 22.31 & 22.68 & 6.16 & 0.66 & 1.37 & 1.74 & 0.06 & 23.93 & 29.34 \\
\hline ANMP & 23.61 & 22.42 & 29.77 & 0.00 & 3.77 & 4.20 & 0.00 & 8.17 & 0.80 \\
\hline FRAF & 18.96 & 28.15 & 19.16 & 3.31 & 3.35 & 3.31 & 4.24 & 5.05 & 6.30 \\
\hline PRFP & 28.82 & 28.39 & 16.17 & 12.72 & 9.16 & 10.71 & 2.43 & 19.42 & 12.68 \\
\hline TXTL & 23.73 & 29.21 & 30.42 & 5.41 & 4.37 & 7.98 & 16.89 & 10.06 & 11.15 \\
\hline HIND & 22.80 & 19.32 & 14.45 & 2.90 & 2.60 & 4.93 & 0.59 & 4.97 & 4.54 \\
\hline ENRG & 3.920 & 17.75 & 26.07 & 0.00 & 1.81 & 1.98 & 0.00 & 0.68 & 1.17 \\
\hline
\end{tabular}

Source: GTAP Database V.6.

\footnotetext{
${ }^{8}$ Although Table 3 presents data for only exports, the figures can also be iterpreted as imports, given that export of a country is the import of its partner country despite the negligible difference arising from the valuation of exports (f.o.b) and imports (c.i.f).
} 
imports from Bangladesh and Malaysia are recorded for PRFP, $12.7 \%$ and $9.2 \%$ respectively. Tariffs for the other sectors are relatively low. Malaysia applies quite low rates for imports from Bangladesh, except for TXTL (16.9\%), compared to imports from Indonesia. The highest import tariffs on Indonesian imports are noted in RAGR (23.9\%), PRFP (19.4\%) and TXTL (10.1\%).

Export subsidies, which are considered as an unfair support mechanism that distort international markets, are of limited concern to our respective countries. Database indicate that (not shown here) Bangladesh does not entail any subsidy or tax on its exports. Indonesia applies taxes, though at a negligible degree, on its ENRG exports to Bangladesh and Malaysia while subsidizing HIND exports to Malaysia. On the other hand, Malaysia supports its ENRG exports to Bangladesh and Indonesia yet again at an insignificant level.

\section{Simulation Results}

This section introduces the results of the FTA simulation with evaluation of its effects on different macroeconomic aggregates of the respective parties focusing on production, trade, and welfare.

\section{A. Real GDP and Sectoral Output}

The results of the simulation indicate that the impact of the FTA on real GDP growth will be quite limited. Expressed by the GDP quantity index-one of the outcomes of GTAP model-, Real GDP growth in Indonesia is measured as $0.01 \%$ while Bangladesh and Malaysia experience declines in real GDP at $0.16 \%$ and $0.02 \%$ respectively.

Output effects by sector in Bangladesh, Indonesia, and Malaysia are presented in Table 6 as a percentage change in output volumes relative to initial output levels. In Bangladesh, there happens to be deterioration in all of the sectors except TXTL, the only sector that improves in all of the three countries. Moreover, the largest structural adjustment in Bangladesh is experienced in TXTL with 3.53\%. In Indonesia, production in ANMP, FRAF, ENRG, and SVCS decreases while in the other sectors, particularly in TXTL $(1.16 \%)$, increases. TXTL, with $9.28 \%$ of increase, is the most expanding sector in Malaysia as well, followed by PRFP and ANMP.

Decomposition of the output change, as presented in Table 7, reveals that the positive contribution mostly comes from the export side. Contribution of the 
Table 6. Impact on Output by Sector (\% change)

\begin{tabular}{lcrrr}
\hline & BANG & INDO & MALY & ROW \\
\hline RAGR & -0.05 & 0.29 & -0.59 & 0.00 \\
ANMP & -0.34 & -0.02 & 1.90 & 0.00 \\
FRAF & -0.74 & -0.47 & -0.35 & 0.01 \\
PRFP & -0.83 & 0.04 & 2.12 & 0.00 \\
TXTL & 3.53 & 1.16 & 9.28 & -0.06 \\
HIND & -1.81 & 0.38 & -0.07 & 0.00 \\
ENRG & -0.72 & -0.68 & -0.37 & 0.01 \\
SVCS & -0.15 & -0.03 & -0.19 & 0.00
\end{tabular}

Source: Simulation results

domestic demand is generally negative. In Bangladesh, this distinction is very clear: export contribution is positive in all of the sectors while the domestic demand contribution is always negative as a result of the vast increase in imports (see Table 9) following the removal of high import tariffs. As for Indonesia, both foreign and domestic demand decrease in FRAF and ENRG. Domestic demand contribution is positive only in TXTL and SVCS. Malaysia, on the other hand, seems to be more advantageous with respect to output response to the liberalization process. Except for ENRG and SVCS, export-oriented output response is positive in all of the sectors, the largest increase being in TXTL (8.4\%), while ANMP, PRFP, TXTL and SVCS also contribute positively as a result of the increase in domestic demand. From table 7, it can be seen that Bangladesh is the only country having positive export contribution for all sectors, especially in TXTL.

Table 7. Decomposition of Output Response between Export and Domestic Demand, by Sector (\% change)

\begin{tabular}{ccccccc}
\hline & \multicolumn{2}{c}{ Bangladesh } & \multicolumn{2}{c}{ Malaysia } & \multicolumn{2}{c}{ Indonesia } \\
\cline { 2 - 6 } & $\begin{array}{c}\text { Export } \\
\text { Contribution }\end{array}$ & $\begin{array}{c}\text { Domestic } \\
\text { Demand } \\
\text { Contribution }\end{array}$ & $\begin{array}{c}\text { Export } \\
\text { Contribution }\end{array}$ & $\begin{array}{c}\text { Domestic } \\
\text { Demand } \\
\text { Contribution }\end{array}$ & $\begin{array}{c}\text { Export } \\
\text { Contribution }\end{array}$ & $\begin{array}{c}\text { Domestic } \\
\text { Demand } \\
\text { Contribution }\end{array}$ \\
\hline RAGR & 0.03 & -0.08 & 0.52 & -0.24 & 0.78 & -1.37 \\
ANMP & 0.01 & -0.36 & 0.10 & -0.12 & 1.53 & 0.37 \\
FRAF & 0.01 & -0.75 & -0.32 & -0.14 & 0.07 & -0.42 \\
PRFP & 0.06 & -0.89 & 0.16 & -0.12 & 1.72 & 0.40 \\
TXTL & 3.75 & -0.22 & 0.95 & 0.22 & 8.41 & 0.87 \\
HIND & 0.41 & -2.22 & 0.57 & -0.19 & 0.01 & -0.08 \\
ENRG & 0.01 & -0.73 & -0.49 & -0.19 & -0.27 & -0.10 \\
SVCS & 0.03 & -0.18 & -0.07 & 0.04 & -0.22 & 0.03 \\
\hline
\end{tabular}

Source: Simulation results 
Table 8. Change in Trade Balance by Sector (Million USD)

\begin{tabular}{lrrrrr}
\hline & BNGL & \multicolumn{1}{c}{ INDO } & MALY & \multicolumn{1}{c}{ ROW } & \multicolumn{1}{c}{ Total } \\
\hline RAGR & 1.28 & 66.15 & -88.82 & 22.42 & 1.02 \\
ANMP & -10.34 & -3.30 & 23.58 & -13.77 & -3.84 \\
FRAF & -21.46 & -44.70 & -34.17 & 107.64 & 7.31 \\
PRFP & -55.90 & 29.68 & 93.44 & -81.23 & -14.01 \\
TXTL & 144.25 & 182.20 & 205.36 & -551.15 & -19.34 \\
HIND & -124.32 & 165.27 & -119.72 & 7.41 & -71.36 \\
ENRG & 5.49 & -161.46 & -49.03 & 213.68 & 8.69 \\
SVCS & 17.41 & -138.30 & -130.44 & 342.86 & 91.52 \\
Total & -43.60 & 95.55 & -99.81 & 47.86 & 0.00 \\
\hline
\end{tabular}

Source: Simulation results

\section{B. Trade Balance}

Table 8 presents the change in trade balance by sector relative to pre-simulation volumes. Overall trade balance in Bangladesh and Malaysia shifts in favor of imports resulting in deficit of $\$ 43.6$ million and $\$ 99.8$ million, respectively. Accordingly, the other two regions, Indonesia and ROW become net exporters with $\$ 95.6$ million and $\$ 47.9$ million, respectively.

Further details by sector reveal that the trade deficit in Bangladesh is mostly caused by HIND, which is the main sector in its exports to Indonesia and Malaysia but which also experiences the largest shrink in output with the highest deterioration in domestic demand. On the other hand, TXTL is the most promising sector with an increase of $\$ 144$ million in its net exports. Although Indonesia experience larger deterioration in some sectors such as ENRG (\$161 million) and SVCS (\$138 million), the improvement in TXTL (\$182 million) and HIND (\$165 million) are large enough to dominate that deterioration, playing a significant role in the overall increase in net exports of the country. Despite the improvement in the trade balance of three sectors, particularly in TXTL with \$205 million, however, Malaysia cannot achieve a positive change in its overall trade balance because of the other sectors which yield a trade deficit.

Notwithstanding the gloomy picture displayed above, Table 9 shows that the suggested FTA enhances the trade among its members at a significant level. Bangladesh's total exports to Indonesia rises $31.1 \%$, TXTL and PRFP taking the lead with each more than $60 \%$ increase. As previously mentioned, these sectors are the ones which Indonesia imposes the highest tariff rates.

Bangladesh's exports to Malaysia rises even more with $46.9 \%$, TXTL by far 
Table 9. Change in Bilateral Exports by Partner Country and by Sector (\%)

\begin{tabular}{|c|c|c|c|c|c|c|c|c|c|c|c|c|}
\hline & \multicolumn{4}{|c|}{ Exports of Bangladesh } & \multicolumn{4}{|c|}{ Exports of Indonesia } & \multicolumn{4}{|c|}{ Exports of Malaysia } \\
\hline & INDO & MALY & ROW & Total & BNGL & MALY & ROW & Total & BNGL & INDO & ROW & Total \\
\hline RAGR & 8.4 & -7.0 & 1.9 & 1.9 & 168.0 & 164.1 & -4.7 & 5.5 & 189.1 & 11.2 & 0.9 & 1.4 \\
\hline ANMP & 6.4 & -0.1 & 3.9 & 3.9 & 289.1 & 64.4 & -3.9 & 2.4 & 281.0 & 34.0 & 0.9 & 3.5 \\
\hline FRAF & 25.9 & 26.3 & 2.5 & 3.1 & 155.6 & 27.3 & -1.7 & -0.4 & 309.9 & 22.5 & -0.3 & 0.2 \\
\hline PRFP & 60.4 & 8.7 & 1.6 & 1.6 & 133.0 & 91.2 & -1.8 & 1.9 & 135.2 & 40.0 & 0.5 & 3.0 \\
\hline TXTL & 60.6 & 229.1 & 6.4 & 6.5 & 318.0 & 92.1 & -2.1 & 1.9 & 512.5 & 45.1 & 3.4 & 10.3 \\
\hline HIND & 29.1 & 8.2 & 3.9 & 4.4 & 298.4 & 39.8 & -1.8 & 1.6 & 225.7 & 20.6 & -0.4 & 0.1 \\
\hline ENRG & 4.7 & 4.7 & 4.4 & 4.4 & 48.0 & 8.5 & -1.7 & -1.6 & 440.7 & 18.8 & -1.3 & -0.8 \\
\hline SVCS & 1.9 & 1.4 & 1.1 & 1.1 & -2.2 & -1.0 & -1.2 & -1.2 & -1.5 & 0.3 & -0.5 & -0.5 \\
\hline Total & 31.1 & 46.9 & 5.4 & 5.5 & 262.5 & 51.1 & -1.9 & 0.9 & 259.0 & 18.5 & -0.3 & 0.4 \\
\hline
\end{tabular}

Source: Simulation results

being the most important sector with an increase of $229 \%$ while exports of RAGR and ANMP decrease. It is worth mentioning that the highest tariff rates on Malaysian imports from Bangladesh are enforced on TXTL. Therefore, it can be claimed for the case of Bangladesh that the sectors which were previously imposed higher tax rates receive the highest increase in their exports following the removal of those taxes.

With the elimination of high tariffs by Bangladesh, Indonesian exports to this country rise $262.5 \%$. SVCS is the only sector the exports of which decreases ($2.2 \%$ ). The increase in the other sectors ranges from $133 \%$ in PRFP to $318 \%$ in TXTL except in ENRG (48\%). As for Indonesian exports to Malaysia, there is also an increase of $51 \%$. Once more, SVCS is the only sector which deteriorates following the removal of tariffs. The largest increase is recorded for RAGR (164\%) along with the removal of the high tariff rate (23.9\%) in Malaysia. The increase in the remaining sectors ranges from $27 \%$ to $92 \%$. Surprisingly, Indonesian exports to ROW decrease in all of the sectors.

Malaysian exports to Bangladesh also rise up sharply (259\%). Similar to the exports of Indonesia, SVCS exports fall down (1.5\%) while the largest increase is observed for TXTL exports (512\%). The increase in exports of the other sectors is also large, ranging from $135 \%$ to $440 \%$. Malaysian exports to Indonesia also increases (18.5\%) but less than the previously mentioned bilateral exports. SVCS is the least affected sector with an increase of $0.3 \%$. One more time, the largest increase is recorded for textile (45.1\%). The growth of exports in PRFP (40\%) and ANMP (34\%) is also significant.

One would realize that there is a remarkable change in intra-industry trade: some 
Table 10. Impact on Regional Welfare (EV, Million \$)

\begin{tabular}{ccccr}
\hline & \multirow{2}{*}{ Change in Welfare } & \multicolumn{3}{c}{ Decomposition of Welfare Change } \\
\cline { 3 - 5 } & & Allocative Efficiency & Terms of Trade & Other \\
\hline BANG & -163.12 & -74.43 & -73.96 & -14.73 \\
INDO & 197.05 & 10.62 & 257.38 & -70.95 \\
MALY & 62.88 & -14.80 & 68.35 & 9.33 \\
\hline
\end{tabular}

Source: Simulation results

sectors have shown an increase or decrease in export volume of 200 to $400 \%$. There are basically two reasons to explain this quite remarkable jump. The first reason is the fact that the initial trade levels are quite low, leading to big percentage changes when there is even modest changes in the amount. The second reason has to do with the degree of initial protection. When Table 9 is reviewed together with Table 4 , it is obvious that the sectors which have shown remarkable jumps are those with higher import taxes before the shocks.

\section{Regional Welfare}

The net welfare gains from a policy change are measured in GTAP by equivalent variation (EV), the change in income that is equivalent to the welfare effect of the policy change, which can be broken down into sub-components in order to decompose the effect by its sources. Accordingly, Table 10 presents the impacts of the studied FTA on regional welfare in terms of equivalent variation. It is apparent that Indonesia and Malaysia seem to benefit from the FTA with a gain of $\$ 197.05$ million and \$62.88 million respectively, unlike Bangladesh which experiences a loss of $\$ 163.12$ million.

Allocative efficiency and terms-of-trade are the main components of the equivalent variation. As such, welfare loss of Bangladesh results mostly from allocative efficiency (\$74.43 million) and terms of trade effects (\$73.96 million) in addition to some loss from other sources. This is not surprising in that the removal of high tariff rates in Bangladesh has resulted in an extensive increase in its imports from other countries, leading to terms of trade losses. In fact both export and import prices fall, but the magnitude is bigger for the latter, hence the negative welfare gain in that front. In Indonesia and Malaysia, where the initial tariff rates were already at relatively low levels, welfare gains mostly come from terms of trade effect, $\$ 257.38$ million and $\$ 68.35$ million respectively. Allocative efficiency also contributes to the increase in welfare with $\$ 10.62$ million in Indonesia while other factors cause a loss of $\$ 70.95$ million. As for Malaysia, while the moderate 
increase in its welfare is generated mostly by improvement in the terms of trade, it gains a small amount from other sources though it suffers a loss of some $\$ 14.8$ million from allocative efficiency.

Table 11 and Table 12 present the further decomposition of two major welfare components to analyze the sectoral sources of welfare results. In Indonesia, the allocative efficiency gain is mostly accrued by HIND. On the other hand, all sectors contribute more homogenously to the terms of trade component though HIND is again the leading sector by $\$ 77.47$ million. In Malaysia, terms of trade losses in PRFP and TXTL attenuates the gains obtained by HIND and SVCS. The negative allocative efficiency of Malaysia stems mostly from the loss of $\$ 16.53$ million in RAGR. For the case of Bangladesh, TXTL sector is the main culprit through both allocative efficiency (\$ -50.86 million) and terms of trade effects ( $\$$ 63.64 million), accounting for $68.3 \%$ and $86 \%$ of the changes, respectively.

One would be curious where does this allocative efficiency losses come from for Bangladesh where normally one would expect an efficiency, hence welfare gain? Digging into this question, we realized that textiles is heavily subsidized in

Table 11. Allocative Efficiency Effect by Commodity Groups

\begin{tabular}{rrrrrrrrrr}
\hline & RAGR & ANMP & FRAF & PRFP & TXTL & HIND & ENRG & SVCS & Total \\
\hline BNGL & 0.21 & -1.99 & -1.14 & 10.27 & -50.86 & -25.34 & -5.86 & 0.29 & -74.43 \\
INDO & 1.42 & 0.51 & -0.93 & 1.66 & -1.27 & 11.78 & -2.55 & -0.02 & 10.62 \\
MALY & -16.53 & 1.00 & -1.18 & 1.86 & 3.34 & -2.99 & -0.53 & 0.22 & -14.80 \\
ROW & 1.68 & -3.03 & -5.82 & -11.82 & -45.50 & -15.29 & -4.53 & -1.11 & -80.33 \\
Total & -13.23 & -3.51 & -9.07 & 1.98 & -94.29 & -31.84 & -13.47 & -0.62 & -158.94 \\
\hline
\end{tabular}

Source: Simulation results

Table 12. Terms of Trade Effect by Commodity Groups

\begin{tabular}{rrrrr}
\hline & BNGL & INDO & \multicolumn{1}{c}{ MALY } & \multicolumn{1}{c}{ ROW } \\
\hline RAGR & -0.70 & 31.03 & -8.54 & -24.47 \\
ANMP & -0.04 & 3.62 & -2.45 & -1.62 \\
FRAF & -0.22 & 37.11 & 1.33 & -38.81 \\
PRFP & -2.09 & 29.88 & -12.87 & -16.42 \\
TXTL & -63.64 & 39.70 & -20.90 & 40.76 \\
HIND & -4.61 & 77.48 & 57.60 & -127.41 \\
ENRG & -0.01 & 18.49 & 8.34 & -25.90 \\
SVCS & -3.55 & 20.45 & 45.90 & -58.63 \\
Total & -74.86 & 257.75 & 68.40 & -252.49 \\
\hline
\end{tabular}

Source: Simulation results 
Bangladesh as refleced by the negative production taxes in the database. Positive output change interacting with negative tax (i.e. subsidy) generates negative welfare gains. The opposite is true for industry (HIND): negative output change is interacting with positive production tax. Combined, these two sectors account for all the action in allocative efficiency: $\$[(-50.86)+(-25.34)]$ million of -74.43 with small offsetting by some other sectors.

Obviously the scenario analyzed in the study is a one-shot full removal of tariffs and subsidies on all sectors. However FTA involving developing countries usually involve gradual removal of trade barriers at varying rates among sectors. For example, it is not unusual to see agriculture exempted from trade liberalization, at least in the beginning. This brings the possibility of a gradual removal of trade barriers scenario. Keeping this in mind, we tried a partial liberalization scenario where we remowed barriers on all other sectors but primary agriculture. However we found no significant difference between these two cases. For instance, output response is found to be $3.49 \%$ as opposed to $3.53 \%$ of the previous scenario, leaving no qualitative difference in any other area.

\section{Conclusion}

East Asia is becoming highly integrated through the flourishing FTAs in the region, driven mainly by integrations of other countries with the ASEAN group the hub of RTAs in the region. In this regard, Indonesia and Malaysia as members of the ASEAN have already been in close economic integration within the group.

Most economic cooperation initiatives or free trade agreements are established with arrangements to facilitate the growth of production and trade of the weaker economies. This study has showed that an FTA among Bangladesh and the two members of the ASEAN would favor Indonesia and Malaysia, with Indonesia gaining much more, while disadvantaging Bangladesh with a small welfare loss. One would think that this outcome highlights the argument, first introduced half a century ago by Myrdal (1957) and Hirschman (1958), on FTAs that trade liberalization is usually accompanied by polarization of trade and investment in favor of more competitive countries with stronger economies initially.

Accordingly, this integration seems likely to lead to a polarization effect rather than an opportunity for joint development, which may be attributed to the differences in the levels of development and size of economies as well as the absence of efficient adjustment mechanisms in Bangladesh. At one side is 
Bangladesh, which is one of the least developed countries with high protection rates, and at the other side are Indonesia and Malaysia, which are of the fastest growing emerging economies with high integration level with the world.

However, it should be noted that generalizations neither on welfare gains of such integration nor on the distribution of these gains are always clear-cut. The results may be different for other scenarios. For example, it would be possible for Bagladesh to have positive welfare results if the negative production subsidies in textiles sector were removed, or if one could prove that these subsidies are nonexistent. Also, provided that the number of OIC member countries in the GTAP database can be increased, it can then be possible to conduct more comprehensive studies on the OIC member countries, which have a wide spectrum of economic development levels.

Given the current result of the study, it can be suggested that mechanisms be developed in order to strengthen the adjustment capacity of the less developed members. Correspondingly, instead of FTAs, preferential trade agreements can be considered in the beginning, as already initiated by the OIC by TPS-OIC, in accordance with the priorities of countries focusing on limited sectors in which they have comparative advantage. Larger integrations may be achieved in the long term gradually through such small-scale integrations.

\section{Acknowledgements}

The authors would like to thank Syed F. Mahmud, anonymous referees, and participants at the Eleventh Annual Conference on Global Economic Analysis (Helsinki, June 12-14, 2008) for their valuable comments and criticism. The views expressed in the paper do not necessarily reflect those of the institutions with which the authors are affiliated. All remaining errors, if any, are our own.

Received 3 July 2008, Revised 5 January 2008, Accepted 8 January 2008 


\section{Appendix 1: Sectoral Aggregation}

\begin{tabular}{|c|c|c|c|c|c|}
\hline \multicolumn{3}{|c|}{ Current Study } & \multicolumn{3}{|r|}{ GTAP } \\
\hline No. & Code & Description & No. & Code & Description \\
\hline \multirow[t]{8}{*}{1} & RAGR & Raw Agricultural & 1 & pdr & paddy rice \\
\hline & & Products & 2 & wht & wheat \\
\hline & & & 3 & gro & cereal grains, nec \\
\hline & & & 4 & $v_{-} \mathrm{f}$ & vegetables, fruits, nuts \\
\hline & & & 5 & osd & oilseeds \\
\hline & & & 6 & $c \_b$ & sugar cane, sugar beet \\
\hline & & & 7 & $\mathrm{pfb}$ & plant-based fibers \\
\hline & & & 8 & ocr & crops, nec. \\
\hline \multirow[t]{7}{*}{2} & ANMP & Animal Products & 9 & ctl & bovine cattle, sheep and goats,horses \\
\hline & & & 10 & oap & animal products, nec. \\
\hline & & & 11 & $\mathrm{rmk}$ & raw milk \\
\hline & & & 12 & wol & wool, silk-worm cocoons \\
\hline & & & 19 & $\mathrm{cmt}$ & $\begin{array}{l}\text { bovine cattle, sheep and goat, horse } \\
\text { meat products }\end{array}$ \\
\hline & & & 20 & omt & meat products, nec \\
\hline & & & 22 & mil & dairy products \\
\hline \multirow[t]{4}{*}{3} & FRAF & Forestry and Fishing & 13 & for & forestry \\
\hline & & & 14 & fsh & fishing \\
\hline & & & 30 & lum & wood products \\
\hline & & & 31 & ppp & paper products, publishing \\
\hline \multirow[t]{5}{*}{4} & PRFP & Processed Food & 21 & vol & vegetable oils and fats \\
\hline & & & 23 & pcr & processed rice \\
\hline & & & 24 & sgr & sugar \\
\hline & & & 25 & ofd & food products, nec. \\
\hline & & & 26 & b_t & beverages and tobacco products \\
\hline \multirow[t]{3}{*}{5} & TXTL & Textiles & 27 & text & textiles \\
\hline & & & 28 & wap & wearing apparel \\
\hline & & & 29 & lea & leather products \\
\hline \multirow[t]{11}{*}{6} & HIND & Industrial Products & 18 & omn & minerals, nec. \\
\hline & & & 33 & $\operatorname{crp}$ & chemical, rubber, plastic products \\
\hline & & & 34 & $\mathrm{nmm}$ & mineral products, nec. \\
\hline & & & 35 & i_s & ferrous metal \\
\hline & & & 36 & $\mathrm{nfm}$ & metals, nec \\
\hline & & & 37 & fmp & metal products \\
\hline & & & 38 & mvh & motor vehicles and parts \\
\hline & & & 39 & otn & transport equipment, nec. \\
\hline & & & 40 & ele & electronic equipment \\
\hline & & & 41 & ome & machinery and equipment, etc. \\
\hline & & & 42 & omf & manufactures, nec. \\
\hline
\end{tabular}




\begin{tabular}{|c|c|c|c|c|c|}
\hline \multirow[t]{6}{*}{7} & ENRG & Energy & 15 & col & coal \\
\hline & & & 16 & oil & oil \\
\hline & & & 17 & gas & gas manufacture, distribution \\
\hline & & & 32 & p_c & petroleum, coal products \\
\hline & & & 43 & ely & electricity \\
\hline & & & 44 & gdt & gas manufacture, distribution \\
\hline \multirow[t]{13}{*}{8} & SVCS & Services & 45 & wtr & water \\
\hline & & & 46 & cns & construction \\
\hline & & & 47 & $\operatorname{trd}$ & trade \\
\hline & & & 48 & otp & transport, nec \\
\hline & & & 49 & wtp & water transport \\
\hline & & & 50 & atp & air transport \\
\hline & & & 51 & $\mathrm{cmn}$ & communication \\
\hline & & & 52 & ofi & financial services, nec. \\
\hline & & & 53 & isr & insurance \\
\hline & & & 54 & obs & business services, nec \\
\hline & & & 55 & $\operatorname{ros}$ & recreational and other services \\
\hline & & & 56 & osg & $\begin{array}{l}\text { public administration and defense, } \\
\text { education, health }\end{array}$ \\
\hline & & & 57 & dwe & dwellings \\
\hline
\end{tabular}




\section{References}

Center for Global Trade Analysis, the Department of Agricultural Economics, Purdue University [http://www.gtap.agecon.purdue.edu/].

The GTAP 6 Data Base: Global Trade, Assistance, and Production (2006) (ed. by B. Dimaranan), Center for Global Trade Analysis, Purdue University.

Hertel, T.W.(1997), Global Trade Analysis: Modeling and Applications, Cambridge University Press.

Hirschman, A.O.(1958), The Strategy of Economic Development, New Haven/Conn.: Yale Univ. Press.

Myrdal, G.(1957), Economic Theory and Underdeveloped Regions, London: Duckworth. PRETAS(2006), Framework Agreement and Preferential Tariff Scheme, Istanbul: COMCEC Coordination Office.

COMCEC, Standing Committee for Economic and Commercial Cooperation of the Organization of the Islamic Conference [http://www.comcec.org/].

UNESCAP(2008), Asia-Pacific Trade and Investment Agreements Database (APTIAD) [http://www.unescap.org/tid/aptiad/agg_db.aspx].

WTO RTA Gateway [http://www.wto.org/]. 